Tér és Társadalom 23. évf. 2009/4. 233-236. p.

Tér és Társadalom

XXIII. évf. 2009 4: 233-240

\title{
BESZÁMOLÓ
}

\section{BESZÁMOLÓ AZ EURÓPAI REGIONÁLIS TUDOMÁNYI TÁRSASÁG 49. KONGRESSZUSÁRÓL}

\author{
(Uniwersytet Łódźki, Łódź, 2009. augusztus 25-29.)
}

\section{ZSIBÓK ZSUZSANNA}

Idén Lengyelországban, Łódź városában tartotta kongresszusát az Európai Regionális Tudományi Társaság, az ERSA (European Regional Science Association). A rendezvényt közösen szervezte a Łódźi Egyetem Város- és Regionális Gazdálkodási Tanszéke, a Lengyel Várostervezók Társasága és az ERSA lengyel szekciója (a Lengyel Tudományos Akadémia Térgazdasági és Regionális Tervezési Bizottsága), mely 2009-ben fennállásának 50. évfordulóját ünnepelte.

A kongresszusnak otthont adó, a 2016-os Európa Kulturális Fơvárosa címre eséllyel pályázó város a kultúra, az oktatás és a szórakozás egyik központjává vált Lengyelországban az elmúlt évtizedben, így az esemény kiváló alkalmat adott a résztvevőknek arra, hogy megfigyeljék környezetükben a gyors fejlódés jeleit. A rendezvény helyszíne, a Menedzsment Kar, az egyik legfiatalabb egysége az egyetemnek, 1994-től folyik itt oktatás. A társszervező Lengyel Várostervezők Társasága már több mint 80 éve egyesíti számos tudományág képviselőit azzal a céllal, hogy a városi és vidéki területek olyan környezetet kínáljanak az emberek számára, amely a szellemi és anyagi szükségleteik kielégítése mellett része a nemzet kulturális örökségének, harmóniában van a természettel és gazdagítja a táj szépségét.

A kongresszus témája a „Területi kohézió Európában és az integrativ tervezés” volt, mely a helyi szervező bizottság elnöke, Tadeusz Markowski szerint az ERSA számára kissé rendhagyó, mégis nagyon fontos terület. Közel 500 résztvevó érkezett a világ 38 országából, és a szervezók 447 tanulmány prezentációjára adtak lehetőséget, melyek közül hetet magyarok nyújtottak be. Az előadások ötféle szekcióban hangzottak el: a plenáris elöadások szekciójában, a referált tanulmányok szekciójában, a „Fiatal tudósok” szekciójában, speciális témák köré szervezett szekciókban (összesen hat témában) és az általános elöadások szekciójában.

A kongresszuson három plenáris elóadást hallgathattak meg a résztvevők. Az elsőt Gilles Duranton, a University of Toronto professzora tartotta „A városok növekedése" címmel. E témakörnek az egyik fö kérdése az, hogy míg a városok folyamatosan növekednek, miért van az, hogy egyes városok gyorsabban növekednek, mint mások. Duranton az előadásában olyan modellt mutatott be, amely az amerikai nagyvárosi régiók 1980 és 2000 közötti adataira épuilt, és a városok méretét a fóutak 
hosszával becsülte meg. Az elöadás arra a következtetésre jutott, hogy a városok méretét meghatározza az ingázási költség, a földhasználat szabályozása és az emberi erỏforrás minősége (az egyetemi hallgatók aránya a város összlakosságán belül). Összességében három fö tényezôt emelt ki, amely hat a városok növekedésére: az ingázási költségek, az agglomerációs elönyök és a város által kínált lehetőségek, mint amilyen például a kedvezỏ klíma vagy a humán tőke.

Piotr Zuber, a lengyel Regionális Fejlesztési Minisztériumból „Területi kohéziós politika - lengyelországi kilátások" címmel tartott plenáris előadást. Megvizsgálta a területi kohézió folyamatát az európai kialakulása, a kohéziós jelentések és a Zöld Könyv (az Európai Bizottság által 2008-ban kiadott „Zöld könyv a területi kohézióról" címü dokumentum) tïkrében. Annak okát kívánta felderíteni, hogy miért bukott meg majdnem minden eddigi lengyelországi nemzeti kohéziós terv. A probléma gyökere Zuber szerint az, hogy Lengyelországban hiányzik az emberek közötti és az állami intézményekbe vetett bizalom, a kapcsolatokat áthatja az idegenekkel szembeni ellenérzés, ami miatt nem müködik az emberek (és az intézmények) közötti kommunikáció. A probléma feloldásában szerinte segítene, ha egyetértést lehetne teremteni a tudomány és a politika képviselői között.

A kongresszus harmadik plenáris előadója Andreas Faludi, a Delft University of Technology professzora volt, előadásának a „Területi kohéziós politika és annak kapcsolódásai" címet adta. Az előadás végigvezette a területi kohézió fogalmának fejlődését az Európai Unió történetének különbözö lépcsőfokain. Faludi a fogalmat a kohézió - koherencia - kooperáció hármasába ágyazta, hiszen az európai területi kohézió elỏmozdításához szükség van a nemzeti kohéziós politikák koherenciájára, ami a szereplök közötti együttmúködésen alapul. Napjaink fejleményei között említette a vitát, mely a kohéziós politika újra-nemzetiesítéséről szól. Meglátása szerint a jövőben a területi elv képes lesz egyesíteni a kohéziós politikákat, amelyre példaként a Balti-tengeri politikát és a Duna-politikát említette.

A referált és az általános témájú szekciókban idén 23 témában várták a jelentkezéseket, melyek kellően tág teret biztosítottak ahhoz, hogy a regionális tudomány müvelői kutatási eredményeik bemutatásához megtalálják a számukra megfelelö szekciót. A benyújtott tanulmányok leggyakoribb kérdéskörei a városok térbeli változásai és a városrehabilitáció; a vállalati mobilitás és a klaszterek, illetve az innováció és a vállalati együttmüködések vizsgálata voltak. Jellemzö témák voltak továbbá a földhasználat, az ingatlanok árazása, különös tekintettel a hedonikus árazásra; a munkaerō-vándorlás, a regionális munkaerö-piacok és a tudástöke; valamint a lakóhelyválasztás. Ezeken kívül sok esetben hallgathattunk olyan elóadásokat, amelyek a regionális kormányzással, az állami beavatkozás területi hatáselemzésével; az emberi és társadalmi tökével; a kulturális illetve kreatív ágazatokkal; a kohéziós politikával; a versenyképességgel vagy a közlekedés elérhetỏsége és a közlekedési mód megválasztása témákkal foglalkoztak.

A regionális tudomány egyik vezető folyóirata, a Journal of Regional Science elsö megjelenésének 50. évfordulója alkalmából plenáris ülést rendeztek a kongresszus keretében, melynek során a résztvevök arra keresték a választ, hogy „Milyen új 
irányok várhatók a regionális tudományban az elkövetkezendő 50 év során?". A folyóirat szerkesztői által tartott öt rövidebb vezérelőadás után egy konszenzus alakult ki arról, hogy az elmúlt időszak két, nagy áttörést hozó területe, az új gazdaságföldrajz és a térökonometria jelentősége el fog halványulni. Két irány kezd körvonalazódni, mely meg fogja határozni a jövő regionális tudományi kutatásait, az egyik a „közelség” szerepe, a másik az, hogy az emberek és a vállalatok hogyan döntenek lakó- és munkahelyük, illetve múködési helyük kiválasztásáról.

A kongresszus résztvevőinek lehetőségük nyîlt arra, hogy a helyszínen felvegyék a kapcsolatot Európa legnagyobb kiadóival, ugyanis öt kiadó kedvezményes vásárlási lehetôséggel egybekötött kiállítást szervezett az esemény időtartama alatt a regionális tudományhoz kapcsolódó kiadványaival.

A konferencia zárórendezvényén történt az Epainos-díjak és az RSAI-dịj átadása, valamint átadták az ERSA zászlaját a következő évi, 50. kongresszus szervezőjének, a svédországi Jönköping képviselőjének. A kongresszus kíséröprogramjaként a résztvevők egy városnéző kiránduláson szemtanúi lehettek a Łódź városában végbemenő gyors, átható fejlődés jeleinek. A két konferenciavacsorán a résztvevőket a város legmodernebb, kulturális negyedében, a Manufakturában látták vendégül, mely kiváló példát mutat arra, hogyan lehet az üresen álló ipari létesítményeket új élettel megtölteni.

2009-ben a szervezők „fenntartható kongresszust” kívántak megrendezni. Ennek az ötletnek az alapja az, hogy a Brit Szabványügyi Hivatal (British Standard Institute) 2007-ben kiadta a Fenntartható Rendezvény Szabványt (Sustainable Event Standard BS 8901), mely megállapította a különféle méretü és típusú rendezvények társadalom- és környezettudatos szervezésének és lebonyolításának követelményeit. Ezeknek három fó célkitüzésük van: a találkozó negatív ökológiai lábnyomának csökkentése; kedvező hatás gyakorlása a helyi társadalomra és infrastruktúrára; valamint költséghatékony találkozó szervezése. Mindezeket a kongresszus rendezői számos hasznos iránymutatással, újrahasznosítható anyagok felhasználásával, faültetési mozgalommal és egy zöld információs pult müködtetésével segítették elő. Remélhetöleg hazánkban is felfigyelnek erre a lehetőségre, és egyre több konferencia fogja a „fenntartható rendezvény" címet viselni. 
Tér és Társadalom 23. évf. 2009/4. 233-236. p.

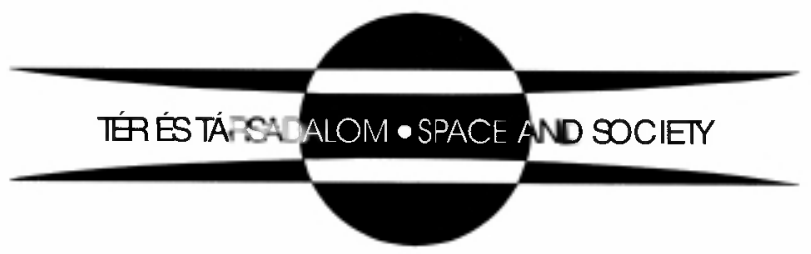

